\title{
EU soft law in the hands of national authorities: The case study of the UK Competition and Markets Authority
}

Citation for published version (APA):

Devine, T., \& Eliantonio, M. (2018). EU soft law in the hands of national authorities: The case study of the UK Competition and Markets Authority. Review of European Administrative Law, 11(1), 49-73. https://doi.org/10.7590/187479818X15282881229829

Document status and date:

Published: 01/01/2018

DOI:

10.7590/187479818X15282881229829

Document Version:

Publisher's PDF, also known as Version of record

\section{Document license:}

Taverne

\section{Please check the document version of this publication:}

- A submitted manuscript is the version of the article upon submission and before peer-review. There can be important differences between the submitted version and the official published version of record.

People interested in the research are advised to contact the author for the final version of the publication, or visit the DOI to the publisher's website.

- The final author version and the galley proof are versions of the publication after peer review.

- The final published version features the final layout of the paper including the volume, issue and page numbers.

Link to publication

\footnotetext{
General rights rights.

- You may freely distribute the URL identifying the publication in the public portal. please follow below link for the End User Agreement:

www.umlib.nl/taverne-license

Take down policy

If you believe that this document breaches copyright please contact us at:

repository@maastrichtuniversity.nl

providing details and we will investigate your claim.
}

Copyright and moral rights for the publications made accessible in the public portal are retained by the authors and/or other copyright owners and it is a condition of accessing publications that users recognise and abide by the legal requirements associated with these

- Users may download and print one copy of any publication from the public portal for the purpose of private study or research.

- You may not further distribute the material or use it for any profit-making activity or commercial gain

If the publication is distributed under the terms of Article $25 \mathrm{fa}$ of the Dutch Copyright Act, indicated by the "Taverne" license above, 


\title{
EU Soft Law in the Hands of National Authorities: The Case Study of the UK Competition and Markets Authority
}

\author{
Thomas Devine \\ Junior Researcher, Faculty of Law, Maastricht University \\ Mariolina Eliantonio* \\ Professor of European and Comparative Administrative Law and Procedure, \\ Maastricht University
}

\section{Introduction}

The principle of sincere cooperation under Article 4(3) TEU is the legal basis used by EU courts to clarify the duties of national courts and administrative authorities in Member States when applying EU law ${ }^{1}$ to ensure that it is applied uniformly on a national level. ${ }^{2}$ The duty of national courts and administrative authorities to apply national law in line with EU law therefore seems to be clear, at least at first sight. There is however uncertainty when judges or public servants are faced with non-legally binding EU law, commonly called 'soft law', ${ }^{3}$ such as recommendations and opinions. ${ }^{4}$

In its Grimaldi judgment, the Court of Justice of the European Union (hereinafter 'CJEU') ruled that national courts are bound to take recommendations - a category of soft law instruments - 'into consideration in order to decide disputes submitted to them. ${ }^{5}$ Although the Court was silent on whether such an obligation stemmed from Article 4(3) TEU, commentators argue that the principle of sincere cooperation is the general principle of EU law underlying

DOI 10.7590/187479818X15282881229829 1874-7981 2018 Review of European Administrative Law

1 Consolidated Version of the Treaty on European Union [2016] OJ C-202/1, art 4(3).

2 John Temple Lang, 'The Development by the Court of Justice of the Duties of Cooperation of National Authorities and Community Institution under Article 10 EC' (2008) 31 Fordham Int'l LJ 1483,1483 f.

3 Francis Snyder, 'Soft law and institutional practice in the European Community', in: Stephen Martin (ed.), The construction of Europe (Springer 1994), 197.

4 Consolidated Version of the Treaty on the Functioning of the European Union [2016] OJ C-202/1, art 288 .

5 Case C-322/88, Salvatore Grimaldi v Fonds des maladies professionnelles [1989] ECLI:EU:C:1989:646, para. 18. 
this obligation. ${ }^{6}$ Article 288 TFEU is clear in that at least two soft law instruments (recommendations and opinions) have no legally binding force; ${ }^{7}$ nevertheless, there is little further guidance on an EU level what other, if any, effects soft law does have. This is because, firstly, treaties are silent beyond what is stated in Article 288 TFEU. Secondly, considering that the Grimaldi saga began in 1989 - 5 years after the Court's Von Colson judgment ${ }^{8}-$ the Court had ample opportunities to clarify the nature of the obligation on national courts and authorities to take soft law into consideration, but has never made use of them. Therefore, although the CJEU has settled that EU soft law instruments in principle have no 'legal effects,' i.e. they do not have legally binding force, it remains unclear whether such instruments can produce 'practical effects,' i.e. those which induce changes in the behaviour and practices of the instrument's addressees and third parties. ${ }^{9}$

One would think that the reason lies in the small relevance of soft law in practice. However, the complete opposite is true: soft law is now widely used in most of the EU's policy areas ${ }^{10}$ and it is unthinkable for businesses to ignore the Commission's Guidelines and Notices and believe they do not affect them." Lawyers constantly use such documents to aid them with interpreting vague Treaty provisions. ${ }^{12}$ To that end, do national courts and authorities also value soft law and use it in cases before them? If there is no clear consistency obligation under EU law with regard to soft law, do bodies in different jurisdictions use it differently? What if, on the other hand, soft law is relied on by businesses and accepted uniformly by different courts and authorities? Does it then not have practical effects that bring soft law close to possessing legal effects of democratically introduced EU legislation? Does this not infringe the rule of law? This type of questions is addressed in the current debate on soft law. ${ }^{13}$

6 Emilia Korkea-Aho, 'National adjudication and transnational soft law: Is Grimaldi still good law?’, Yearbook of European Law (2018) (forthcoming), ft 6.

7 TFEU, art 288.

8 Oana Stefan, 'European Competition Soft Law in European Courts: A Matter of Hard Principles?' (2008) 14(6) European Law Journal 753, 767f; Case 14/83, Sabine von Colson and Elisabeth Kamann $v$ Land Nordrhein-Westfalen [1984] ECLI:EU:C:1984:153.

9 Case C-16/16 P, Kingdom of Belgium v European Commission [2018] ECLI:EU:C:2018:79, Opinion of AG Bobek, para. 88. Note, also, that what the authors refer to as 'legal effects' and 'practical effects' is referred to in CJEU jurisprudence as, respectively, 'binding legal effects' and 'legal effects'.

10 Daniel Wincott, 'Looking Forward or Harking Back? The Commission and the Reform of Governance in the European Union' (2001), 39 Journal of Common Market Studies 897, 899901.

11 With regard to competition law, see: Håkon A. Cosma and Richard Whish, 'Soft Law in the Field of EU Competition Policy' (2003) 14(1) EBLR 25, 31.

12 Arts 101 and 102 TFEU are examples in the field of competition law; Cosma (n 11), 31.

13 For arguments for and against soft law, see: Cosma (n 11), $32 \mathrm{ff}$. 
Prior research has focused mainly on the use of EU soft law by the EU Courts and, to a lesser extent, on the use of EU soft law by national courts. Empirical studies of cases decided by the CJEU have shown that EU soft law does not have legally binding force and is considered to be an interpretation aid more than anything else. However, it may have legally binding effects when it is published by an EU institution that thereby limits its discretion, or when soft law amounts to individual decisions that create specific legitimate expectations. ${ }^{14}$ Relevant case law has shown that general principles of law, as found in the Treaties, give soft law its, albeit limited, legal effects. ${ }^{15}$ Some research has also been conducted on the use of EU competition soft law by national courts in the UK, Netherlands, ${ }^{16}$ France and Germany, ${ }^{17}$ according to which courts do, in principle, apply EU soft law instruments.

Ambiguity regarding the effects of soft law is even larger for national administrative authorities, since, despite falling within the scope of the sincere cooperation obligation, ${ }^{18}$ the Grimaldi judgment only applies to national courts. A field that thus merits close attention is EU competition soft law. Firstly, since the adoption of Regulation 1/2003, ${ }^{19}$ National Competition Authorities (hereinafter 'NCAs') have the power to apply and enforce Articles 101 and 102 TFEU themselves. Secondly, more and more competition cases are enforced by NCAs with the development of the European Competition Network. Thirdly, if before the Regulation 1/2003 the Commission had the sole enforcement power but was nevertheless legally bound by the soft law it issued, ${ }^{20}$ NCAs now enforce competition law without such a legal obligation. This causes uncertainty to businesses that must ensure their compliance with EU competition law and thereby makes the ambiguity surrounding the use of EU soft law by NCAs especially problematic.

To address this issue, this article chooses to use the UK Competition and Markets Authority (hereinafter 'the CMA') as a case study. ${ }^{21}$ Seeing how the CMA uses EU soft law would supplement research already conducted on the

14 Oana Stefan, Soft Law in Court: Competition Law, State Aid and the Court of Justice of the European Union (Kluwer Law International 2013), 179.

15 Ibid., 181.

16 Zlatina Georgieva, 'The judicial reception of competition soft law in the Netherlands and the UK' (2016), 12(1) European Competition Journal 54.

17 Zlatina Georgieva, 'Competition Soft Law in French And German Courts: A Challenge for Online Sales Bans Only?’ (2017) 24(2) Maastricht Journal of European and Comparative Law 175.

18 Lang (n 1), 1529.

19 Council Regulation (EC) No 1/2003 of 16 December 2002 on the implementation of the rules on competition laid down in Articles 81 and 82 of the Treaty [2003] OJ L1/1 (hereinafter 'Regulation 1/2003').

20 Stefan (n 14), 167ff; Case C-189/02 P, Dansk Rørindustri A/S v Commission of the European Communities [2005] ECLI:EU:C:2005:408, para. 12.

21 The CMA is the National Competition Authority of the UK. 
use of those instruments by UK courts ${ }^{22}$ as well as by other NCAs ${ }^{23}$ and would contribute to vertical and horizontal comparisons in future research.

The purpose of this article is, therefore, to answer the question of how the CMA in the United Kingdom uses EU competition soft law instruments in deciding cases before it. In Section 2, the possibilities for the CMA to use soft law on the basis of positivism or hybrid theories are established. Section 3 outlines the methodology used in the article. Section 4 briefly sets out the legal framework for how the CMA should engage with soft law under UK and EU law. In Section 5, the empirical findings are presented, followed by an analysis in Section 6 of the general trends that were identified. Conclusions are provided in Section 7.

\section{Theoretical Framework}

The aim of this article is to examine how the CMA uses EU soft law instruments, where the term 'to use' encompasses different attitudes the CMA can adopt towards EU soft law in its decisions. Following the theoretical framework that Georgieva devised to categorise (non-) recognition of soft law by UK courts, the hypothesis is that the CMA can either accept to recognise soft law instruments or refuse their recognition. ${ }^{24}$

Decisions of the CMA that fall within the first category would confirm the 'hybrid' nature of the law, according to which soft law instruments are considered instruments 'in their own right, [consciously designed with a view] to complete and further detail the provisions of regulations or directives. ${ }^{25}$ It would mean that the CMA recognises the importance of new tools of governance, such as the Commission's policy-making powers, and competition soft law's role as a tool to ensure flexible governance and consistent enforcement of EU law. $^{26}$

Whether the hybridity theory is followed is, however, not binary. As Terpan writes, there is a continuum of views that can be taken on the validity of soft

\section{Georgieva (n 16).}

23 For instance, see: Axel Kallmayer, 'Die Bindungswirkungen von Kommissionsmitteilungen im EU-Wettbewerbsrecht - Mehr Rechtssicherheit durch Soft Law', in: Christian Calliess (ed.), Herausforderungen An Staat Und Verfassung: Völkerrecht - Europarecht-Menschenrechte (Nomos 2015), 662-682; Catherine Vincent, 'La Force Normative des Communications et Lignes Directrices en Droit Européen de la Concurrence’, in: Catherine Thibierge (ed.), La Force Normative (Bruylant 2009), 691-457.

24 Zlatina Georgieva, 'Soft Law in EU Competition Law and Its Judicial Reception in Member States: A Theoretical Perspective' (2015), 16(2) German Law Journal 223, 259

25 Stefan (n 14), 229.

26 David Gerber \& Paolo Cassinis, "The "Modernization” of European Community Competition Law: Achieving Consistency in Enforcement: Part 1' (2006), 27 European Competition Law Review 10,15 . 
law. ${ }^{27}$ Hence, following Georgieva's framework, CMA decisions can be further subdivided into those where the CMA agrees with an instrument explicitly, thereby expressing its acceptance of the instrument. Alternatively, the CMA can agree with an instrument implicitly if it was persuaded by the content of soft law but chose not to make in-text references. The latter sub-category follows the 'persuaded judiciary' theory, which was also hypothesised in Georgieva's study. ${ }^{28}$

CMA decisions that fall within the second category would, on the other hand, confirm a formalistic view on the law, i.e. soft law instruments do not have legally binding force and can therefore be disregarded completely. Refusal of recognition can be expressed, for instance, when the authority explicitly mentions a soft law instrument but refuses to give it any practical or legal effects and omits it from further analysis.

Alternatively, refusal can be expressed by implicitly rejecting soft law, leading to 'neglect'. For instance, this can be the case when an undertaking under investigation uses soft law in an argument in its Statement of Objections, but the CMA ignores the soft law entirely.

\section{Methodology}

When referring to the UK competition authority in general, the term 'CMA' is used and should be viewed as including its predecessor, the Office of Fair Trading (hereinafter 'OFT') ${ }^{29}$ To test the adherence of the CMA to either of the abovementioned theories, the framework is used to categorise references to soft law made in CMA decisions from May 2004 to December 2017. Decisions of the OFT will be used for the period of May 2004 to March 2014 because it carried out the CMA's functions under the Competition Act 1998 (hereinafter 'CA 98') in enforcing EU competition law prior to the introduction of the Enterprise and Regulatory Reform Act 2013. Only decisions from May 2004 onwards are analysed since that is when the decentralisation Regulation $1 / 2003$ became applicable. ${ }^{30}$ Moreover, only those OFT and CMA decisions closed under the CA 98 are considered, which led either to an infringement of Chapters I or II of CA 98, or which led to 'no grounds for action' decisions. ${ }^{31}$

27 Fabien Terpan, 'Soft Law in the European Union - The Changing Nature of EU Law' (2014) 21(1) European Law Journal 68, 70.

28 Georgieva (n 16), 57.

29 Richard Whish and David Bailey, Competition Law (8th edn, OUP 2015), 63f.

30 Regulation $1 / 2003$, Art 45 .

31 Two remarks are necessary: (1) it should be noted that this excludes sectoral regulators that also have the power to find infringements of CA 98; (2) only decisions with one of the three outcomes are considered in this article, since other possible outcomes include 'commitments' and 'administrative priorities', in which the CMA does not engage with the substance of any particular cases. 
This article only addresses decisions that contain at least one of the following five Commission-issued soft law instruments. The first four are the Vertical Guidelines, ${ }^{32}$ Horizontal Guidelines, ${ }^{33}$ 101(3) Guidelines ${ }^{34}$ and the Guidance Paper. ${ }^{35}$ As Georgieva writes, those are the four most referred to substantive soft law instruments in the field of competition law, ${ }^{36}$ which are hence well-fit for examining the CMA's use of EU soft law in general. In addition, the Fine Imposition Guidelines, ${ }^{37}$ a procedural soft law instrument, ${ }^{38}$ is included in the scope of this article in order to establish whether the CMA uses substantive soft law instruments differently from procedural ones.

To compile and analyse the relevant decisions, they were first located on the website of the UK Government where all decisions are summarised and original full versions published. ${ }^{39}$ An incurred constraint was that confidential decisions are not published on the database. Any findings should have regard to this; however, there is no reason suggesting that the CMA would use soft law differently in its confidential decisions. The OFT decision database in the National Archives was used for finding decisions of the $\mathrm{OFT}^{40}$ and the terms inserted

32 European Commission Guidelines on Vertical Restraints [2010] OJ C130/o1; When analysing decisions closed prior to 2010 , the older version of the Guidelines is used: Commission Notice - Guidelines on Vertical Restraints [2000] OJ C291/01.

33 European Commission Guidelines on the applicability of Article 101 of the Treaty on the Functioning of the European Union to horizontal co-operation agreements [2011] OJ C11/O1.

34 European Commission Guidelines on the application of Article 81(3) of the Treaty [2004] OJ $\mathrm{C} 101 / 97$.

35 Communication from the Commission - Guidance on the Commission's enforcement priorities in applying Article 82 of the EC Treaty to abusive exclusionary conduct by dominant undertakings [2009] $\mathrm{OJ} \mathrm{C}_{45} / 7$.

36 Georgieva (n 16), 61.

37 Guidelines on the method of setting fines imposed pursuant to Article 23(2)(a) of Regulation No $1 / 2003$ [2006] OJ C210/2.

38 The difference lies in that the Fine Imposition Guidelines are considered 'application' soft law. This is different from 'scope' soft law instruments and has not yet been dealt with by the CJEU. For more, see: Georgieva (n 16), ft 31.

39 UK Government website, Competition and Markets Authority case database, https://www.gov.uk/cma-cases, accessed on 3 December 2017. Since only those decisions issued under the CA 98 were required, the cases were filtered by 'CA98 and civil cartels'. However, since the database search tool did not function with regard to advanced search syntax needed for the purpose of the study, the website-specific search function on https://www.google.co.uk/ was used. This was done by adding the following to the search bar: <site:https://assets.publishing.service.gov.uk/media/ "Competition Act 1998" AND "Decision of the" $>$. The latter two phrases were added in order to filter the decisions by only the ones issued under the CA 98 . Office of Fair Trading case database (archived),

http://webarchive.nationalarchives.gov.uk/20140402160917/http://www.oft.gov.uk/OFTwork/competition-act-and-cartels/ca98/decisions/, accessed on 3 December 2017. As with the search for CMA decisions, https://www.google.co.uk/. was used. The following was inserted into the search bar: <site:http://webarchive.nationalarchives.gov.uk "Competition Act 1998" AND "Decision of the" $>$. 
into the search engines coincided with the formal and shortened ${ }^{41}$ titles of the respective soft law instruments.

References falling under the 'persuasion' category of the framework were determined based on a compilation of search terms that reflected the vocabulary unique to the instruments in question. ${ }^{42}$ It is hypothesised that, if the CMA adopts the same language as a particular soft law instrument does and reaches a conclusion that is consistent with that instrument, it must have done so because of being persuaded by the instrument. However, it should be noted that such a methodology is constrained by the text of the decisions and cannot derive the particular thoughts of the CMA representative(s) choosing whether to accept or reject soft law instruments. ${ }^{43}$

Finally, it was occasionally found that the CMA explicitly referred to the same instrument repetitively whilst dealing with a single legal issue. ${ }^{44}$ For such purposes, a 'reference' to soft law throughout CMA decisions is defined as a mention of a particular instrument, either in-text or in footnotes, with regard to a particular legal issue. Multiple repetitive references were, therefore, grouped and counted as one. Additionally, generic references that did not apply soft law to a legal issue (e.g. 'The CMA will have regard to the Commission's Article 101(3) Guidelines. ${ }^{45}$ ) were not counted as 'references'.

\section{Legal Framework}

In order to determine how the CMA uses EU soft law, there is a presumption that it does so in accordance with the law - in so far as possible, at least. This Section therefore presents the status quo of the law that shapes the CMA's duty to use EU soft law.

It is evident that, as an EU national administrative authority, the CMA must apply EU law in accordance with Article 4(3) TEU. The duty was formed through a body of case law decided by the CJEU in the 1980 s and is now firmly established as the duty of national courts and authorities to give full effect and con-

41 For example, 'Vertical Guidelines' or 'Guidance Paper'.

42 The following terms were searched for. Vertical Guidelines: 'agency agreements', 'selective distribution systems', 'upfront access payment', 'category management agreement'; 101(3) Guidelines: 'consumer pass-on', 'indispensability criterion', 'two-fold test'; Horizontal Guidelines: 'age of data', 'joint selling agreements', 'qualitative efficiencies'; Guidance Paper: 'equally efficient competition', 'AAC', 'LRAIC', 'anti-competitive foreclosure'. For a more detailed overview of the selection of terms, see: Georgieva (n 16), $\mathrm{ft} 39$.

43 Interviews can be conducted with the CMA to ascertain references in which it implicitly accepted or rejected soft law instruments.

44 For example, see: CMA Decision Conduct in the ophthalmology sector (2015) CE/9784-13, fts 759761.

45 CMA Decision Online sales of posters and frames (2016) 50223, para. 5.82. 
sistent interpretation to EU law. ${ }^{46}$ This duty is even clearer for competition authorities, as Article 3 of Regulation 1/2003 introduces a cooperation obligation on authorities and courts in the field of competition law. The Article's domestic counterpart is Section 60 of the CA 98, according to which UK courts and authorities must ensure consistency of their decisions with EU law. This also applies to the CMA. ${ }^{47}$

The scope of this duty is, however, much less clear when EU soft law is concerned. Several cases have been decided by the CJEU on the consistency duty in case of EU soft law, but only with regard to national courts rather than administrative authorities. The first case where the effects of a Commissionissued Recommendation were discussed was the Grimaldi case about an Italian worker in Belgium wishing to rely on a Commission Recommendation introducing a European schedule of occupational diseases which would have allowed him to receive compensation for a disease he had. The Court held that 'national courts are bound to take recommendations into consideration in order to decide disputes submitted to them, ${ }^{, 48}$ and that instruments alike possess certain legal effects. The interpretation of the duty to 'take into consideration' has proven most difficult, even in the later judgements of the Court. In its 2016 Koninklijke ruling, the Court, without even citing Grimaldi, seemingly reversed the duty on national courts for using Commission Guidelines, stating that courts 'may depart' from the interpretation given in a soft law instrument whenever such departure is justified by the facts of the case. ${ }^{49}$ However, the ruling was likely brought to such an extreme due to the sensitivity of the facts: the Commission Recommendation in question conflicted with national hard law, and, had the CJEU relied on the Grimaldi doctrine, national law would have been disregarded by the Dutch court..$^{\circ}$ Therefore, the duty of national courts is currently still far from clear; the precise scope of the Grimaldi duty still remains to be seen.

The abovementioned case law should not be assumed to also apply to the CMA for at least two reasons. Firstly, the CMA is not a national court and can only be subjected to similar duties through general principles under EU law. ${ }^{51}$ Secondly, even if the case law does have an impact on the duties of national administrative authorities, it is difficult to say whether the duties would remain the same for the CMA, since none of the case law has dealt with soft law instruments in the field of competition law.

Lang (n 2), 1489 .

Whish (n 29), 396.

Grimaldi case (n 5), para. 18.

Case C-28/15, Koninklijke KPN and Others $v$ Autoriteit Consument en Markt (ACM) [2016] ECLI:EU:C:2016:310, para. 39ff.

Korkea-Aho (n 6).

Ibid., ft 6 . 
One of the few cases in which the CJEU dealt explicitly with the nature of the obligations that NCAs have with regard to soft law is the 2012 Expedia case..$^{52}$ In this case, the CJEU stated that NCAs 'may take into account [Commission Notices,] but [are] not required to do so. ${ }^{53}$ This duty imposed on NCAs, if regarded as a duty at all, is significantly looser than the one imposed by the Court in its Grimaldi case law. On the one hand, this could be because, in the Expedia case, the instrument in question was the 2001 version of the de minimis Notice. ${ }^{54}$ The Notice was a 'scope' instrument that dealt with the market share thresholds for determining when competitors appreciably restrict competition, ${ }^{55}$ rather than with interpretation of the substantive content of Articles 101 and 102 TFEU. ${ }^{56}$ On the other hand, the CJEU stated that the Commission's intention with its Notices (not only de minimis) is to provide guidance to courts and authorities in their application of the relevant provisions. ${ }^{57}$ It therefore seems, as Stefan suggests, that the CJEU is certain that soft law does not have binding legal effects on authorities. ${ }^{58}$ However, as the Court also admitted in its Pfleiderer ruling, the Commission Guidelines, although aimed at merely clarifying the Commission's decision-making, 'may have some effect on the practice of the national competition authorities. "' This focus on the practical effects of applying soft law instruments is unclear and remains to be seen in future EU case law and CMA decisional practice.

In national law, the CMA is bound by section 60(3) of the CA 98, which states that 'must (...) have regard to any relevant decision or statement of the Commission.' There, statements can be seen as soft law instruments issued by the Commission ${ }^{60}$ but no explanation is given on the scope of the duty 'to have regard' of such instruments. ${ }^{61}$ In the OFT's MasterCard decision in $2005,{ }^{62}$ it has interpreted the duty as having 'to give serious consideration' to the Commission's statements. However, one can see that such an interpretation is significantly stricter than the more recent one stemming from Expedia-like case law. As will be seen in the following Section, the CMA has been using the looser

\footnotetext{
52 Case C-226/11, Expedia Inc. v Autorité de la concurrence and Others [2012] ECLI:EU:C:2012:795.

53 Ibid., para. 31.

54 Commission Notice on agreements of minor importance which do not appreciably restrict competition under Article 81(1) of the Treaty establishing the European Community (de minimis) [2001] OJ $\mathrm{C}_{3} 68 / 13$.

55 Ibid., para. 7 .

56 Georgieva (n 16), ft 31.

57 Expedia case (n 52), para. 28.

58 Oana Stefan, 'Relying on EU Soft Law Before National Competition Authorities: Hope for the Best, Expect the Worst' (2013) July 2013 (1) CPI Antitrust Chronicle 6.

59 Case C-360/o9, Pfleiderer AG v Bundeskartellamt [2011] EU:C:2011:389, para. 23.

Go Ibid.

61 For an opinion on section 6o, see: Shaun Goodman, 'The Competition Act, section 6o - the governing principles clause' (1999), 20 European Competition Law Review 73.

62 OFT Decision MasterCard UK Members Forum Limited (2005) CA98/05/05, paras 107-116.
} 
Expedia-based scope for interpreting section 6o(3) in its decisions ever since the case Expedia has been ruled.

To conclude, the above suggests that, strictly speaking, it is not legally binding for the CMA to follow statements of the Commission. ${ }^{63}$ Nevertheless, the language of the duty to 'have regard' to Commission soft law and the fact that it is inscribed in national law make it more likely that soft law generates practical effects in the CMA's practice.

\section{Empirical Findings}

For a detailed account of the CMA's attitude towards using Commission soft law instruments, the overall data is first presented. This is followed by an explanation of the references that fell within each of the categories under the theoretical framework. An analysis of the trends found in CMA practice with regard to EU soft law instruments will also be made.

\subsection{Overview of Found Data}

26 CMA decisions were found within the scope of the methodology outlined above. Whenever decisions outside of this scope, but nevertheless relevant, are discussed throughout this article, they are referred to accordingly. The proportion of decisions identified is high since the overall number of decisions taken by the OFT or CMA under the Competition Act 1998 since May 2004 until December 2017 is only $41 .{ }^{64}$ The proportion of decisions containing references to soft law could be even higher, particularly because the total includes confidential decisions. ${ }^{65}$ Hence, the data collection yielded that at least 26 out of the 41 CMA decisions refer to one or more of the soft law instruments under consideration.

The collected decisions often contain a section on the 'Application of section 60 of the Act - consistency with EU law,' ${ }^{66}$ in which the CMA establishes its consistency obligation. Particularly, the CMA states that it must 'under section 60 (3) of the Act, (...) have regard to any relevant decision or statement of the European Commission, ${ }^{67}$ which is seen to include Commission Notices,

63 Goodman (n 61).

6431 decisions by the CMA or OFT were issued between May 2004 and June 2014, according to Whish (n 29), 398-412; 10 decisions by the CMA were issued between June 2014 and December 2017, according to a search on the CMA database.

65 Summaries of confidential decisions are published on the CMA and OFT databases. For example, see: CMA Decision Sports bras RPM investigation (2014) CE/9610-12, https://www.gov.uk/cma-cases/sports-bras-rpm-investigation, accessed on 29 January 2018.

66 OFT Decision Distribution of Mercedes-Benz commercial vehicles (trucks) (2013) CE/9161-09, 56.

67 For example, see: OFT Decision Tobacco (2010) CE/2596-03, 37. 
Guidelines and Communications. ${ }^{68}$ However, there are also decisions where such a section is either omitted completely ${ }^{6}$ or only stated when the CMA refers to a particular instrument. ${ }^{70}$ The CMA never elaborates on the meaning of 'having regard'. In addition, the mention of the section 6o(3) consistency obligation is, in most decisions, the only point where the CMA provides a grounding for using soft law instruments throughout the decisions.

Another noteworthy observation about the section is that, since the CJEU's Expedia ruling, the case has increasingly been mentioned by the CMA in clarifying its section $6 \circ(3)$ obligation 'to have regard' to soft law. ${ }^{71}$ In particular, the CMA refers to paragraph 31 of the Expedia ruling and states, e.g. in the Romabranded mobility scooters decision, that 'the [CJEU] recently held that national competition authorities "may take into account" guidance contained in nonlegally binding Commission Notices (specifically the [de minimis Notice]), but such authorities are not obliged to do so. ${ }^{72}$ It is interesting to note that the CMA used the judgment to give a generally narrow scope to its section 6o(3) obligation considering that the Court in Expedia stressed that its analysis was only applicable to 'scope' instruments such as the de minimis Notice. Moreover, none of the collected decisions used the MasterCard interpretation of section 6o(3) 'to give serious consideration' to soft law. At first sight, this indicates that the CMA is trying to distance itself from giving any form of legal or practical effects to soft law instruments.

This should not, however, suggest that the CMA is reluctant to apply Commission soft law in its decisions. On the contrary, from the dataset of 26 decisions, the CMA made 80 references to soft law instruments. Firstly, the number of references significantly exceeds the number of decisions because in many of them the CMA cites more than one soft law instrument and each instrument more than once. This is not surprising bearing in mind that the length of the decisions collected can be up to 730 pages. ${ }^{73}$

The majority of the 80 references were made to the 101(3) Guidelines $(32$ references) and to the Vertical Guidelines (23 references). Significantly fewer references were made to the Horizontal Guidelines (12 references) and the

68 Goodman (n 61), 5.

69 CMA Decision Galvanised steel tanks for water storage information exchange infringement (2016) $\mathrm{CE} / 9691 / 12$; No reference is made to section 6o(3) at all, despite the CMA referring to the Horizontal Guidelines later in the decision.

70 For example, see: OFT Decision Mobility scooters supplied by Pride Mobility Products Limited: prohibition on online advertising of prices below Pride's RRP (2014) CE/9578-12, para. 3.248: 'In interpreting the VABER, the OFT (and any court) must also have regard to statements of the European Commission, including the Vertical Guidelines (see section 6o(3) of the Act). In this regard, the OFT notes that the Vertical Guidelines: (...).'

${ }^{71}$ In 6 out 15 decisions since the Expedia ruling.

72 OFT Decision Roma-branded mobility scooters: prohibitions on online sales and online price advertising (2013) CE/9578-12, ft 282.

73 For example, see: Tobacco Decision (n 67). 
Guidance Paper (11 references). Finally, the least references were made to the Fine Imposition Guidelines (2 references).

In accordance with the theoretical framework, the collected references are categorised in the forthcoming Sections, albeit with several necessary adaptations. ${ }^{74}$ Overall, it is clear that in almost all (78 out of 80 ) of the references, the CMA accepted soft law instruments and readily engaged with them in the analyses of its decisions. Therefore, a preliminary look at the data already suggests that the reception of the soft law instruments in CMA practice has been largely positive.

The framework originally envisaged that if the CMA accepts a soft law instrument, it will do so either by explicitly referring to it or by using it implicitly. However, throughout the data collection, the 'explicit acceptance' category was split into two sub-categories. This is because in the collected decisions it was recognised that the CMA can explicitly agree with an instrument to varying extents.

Hence, the 76 instances where the CMA explicitly accepted soft law can be split into two categories. First, 40 references where it did so while simultaneously relying on case law on which the instrument is based. It did so either by first citing the CJEU case law on the matter and then referring to the relevant instrument, ${ }^{75}$ or by amounting soft law instruments to summaries of the Court's case law. ${ }^{76}$ Second, 36 references were made to soft law instruments without any mention of CJEU case law in connection with the soft law. The reasons for the CMA doing so and the subsequent implications will subsequently be discussed.

Significantly fewer instances of implicit acceptance and of explicit/implicit refusal have been identified in the decisions. Namely, in 2 references to the 101(3) Guidelines the CMA could have been persuaded by the Guidelines. Another reference that came close to implicit acceptance was to the Guidance Paper. ${ }^{77}$ Lastly, the perhaps unsurprising finding was that the only refusals of the CMA were with the Fine Imposition Guidelines, a procedural soft law instrument. Out of the 2 references, one was explicitly made in Dairy retail price initi-

CMA Decision Conduct in the modelling sector (2016) CE/9859-14, ft 346: 'Judgment in Commission v Volkswagen AG, C-74/04P, ECR, EU:C:2006:460, paragraph 39; Commission Notice: Guidelines on Vertical Restraints, OJ C 130, 19 May 2010, paragraph 25.'

CMA Decision Online resale price maintenance in the bathroom fittings sector (2016) CE/9857-14, para. A.30: 'The Commission's Vertical Guidelines, summarising the relevant case law and citing the judgments of the CJ, describe the two ways (which can be used jointly) to establish acquiescence to a unilateral policy: (...).'

77 See Section 5.3. 
atives, ${ }^{78}$ while the second one was the neglected mention of the Guidelines in the Tobacco decision. ${ }^{79}$

\begin{tabular}{|c|c|c|c|c|c|c|}
\hline \multirow[b]{2}{*}{$\begin{array}{l}\text { Categorisation / } \\
\text { Instrument }\end{array}$} & \multicolumn{3}{|l|}{ Acceptance } & \multicolumn{2}{|l|}{ Refusal } & \\
\hline & $\begin{array}{l}\text { Explicit - } \\
\text { with case law }\end{array}$ & $\begin{array}{l}\text { Explicit - } \\
\text { without } \\
\text { case law }\end{array}$ & $\begin{array}{l}\text { Implicit - } \\
\text { 'persuasion' }\end{array}$ & $\begin{array}{l}\text { Explicit } \\
\text { refusal }\end{array}$ & $\begin{array}{l}\text { Implicit refusal - } \\
\text { 'neglect' }\end{array}$ & \\
\hline $\begin{array}{l}\text { Vertical } \\
\text { Guidelines }\end{array}$ & 16 & 7 & - & - & - & 23 \\
\hline $\begin{array}{l}\text { Horizontal } \\
\text { Guidelines }\end{array}$ & 6 & 6 & - & - & - & 12 \\
\hline Guidance Paper & 5 & 6 & - & - & - & 11 \\
\hline 101(3) Guidelines & 13 & 17 & 2 & - & - & 32 \\
\hline $\begin{array}{l}\text { Imposition of } \\
\text { Fines }\end{array}$ & - & - & - & 1 & 1 & 2 \\
\hline Total & 40 & 36 & 2 & 1 & 1 & 80 \\
\hline \multicolumn{6}{|c|}{ Decisions collected: } & 26 \\
\hline
\end{tabular}

Table 1: Overview of references per instrument and per attitude.

\subsection{Acceptance - Explicit Recognition of Soft Law}

As was seen above, the attitude adopted by the CMA in 76 out of 80 references was an 'explicit acceptance'. Hence, each of the soft law instruments in question, except for the Fine Imposition Guidelines, is generally accepted by the CMA in practice. Overall, the CMA made 40 references to soft law in the 'Explicit - with case law' category. However, it made 36 of them in the 'Explicit - without case law'.

The need to sub-categorise cases of explicit acceptance of soft law instruments becomes clear when one considers the nature of soft law issued by the Commission. In accordance with Article 17(1) TEU, one reason for the Commission's competence to issue soft law instruments is the necessity to provide guidance on how an existing body of law should be interpreted and applied. ${ }^{80}$ For this reason, there are provisions in each of the instruments under consideration regarding its relation to case law of the EU Courts. ${ }^{81}$ Thus, soft law in-

\footnotetext{
78 OFT Decision Dairy retail price initiatives (2011) CE/3094-03.

79 Tobacco Decision (n 67).

80 Whish (n 11), 50.

81 Vertical Guidelines, para. 1(4); Horizontal Guidelines, para. 1.1.9; Guidance Paper, para. 3; 101(3) Guidelines, para. 7 .
} 
struments are essentially based on CJEU case law and are occasionally supplemented by the Commission's own policies. ${ }^{82}$

Out of the collected references, the CMA's acceptance with referral to EU case law can happen in several different forms. An exemplary reference to the Vertical Guidelines in such a situation can be seen in the Online resale price maintenance in the bathroom fittings sector decision, ${ }^{83}$ where the CMA dealt with methods for establishing unilateral policies in cases of vertical agreements. There, the Authority clearly stated that the 'Commission's Vertical Guidelines, summarising the relevant case law and citing the judgments of the [CJEU] describe the two ways (which can be used jointly) to establish acquiescence to a unilateral policy: (...). ${ }^{, 84}$

Alternatively, decisions were also found wherein the CMA simply referred to soft law instruments and relevant case law on which they are based alongside each other. For instance, in the Pride Mobility Products decision, the CMA, dealing with a similar acquiescence issue, stated that 'the Commission's Guidelines on Vertical Restraints (...), citing the judgment of the [CJEU] in Commission v Volkswagen AG and the judgment of the GC in Bayer AG v Commission, summarise the two ways (which can be used jointly) to establish acquiescence to a unilateral policy: (...). ${ }^{85}$

In both of the above decisions, the CMA refers to the Vertical Guidelines and elaborates on the substance of the instruments, which is then followed to solve the issue addressed in the decision. Therefore, it can be said that the CMA's attitude amounts to explicit acceptance of the Vertical Guidelines. This can also be seen from its other references to the Vertical Guidelines, amongst others.

This attitude to soft law is recognisable from the "case-law-read-togetherwith-soft-law' approach, which Georgieva also determined to be commonplace in her study on soft law use in UK courts. ${ }^{86}$ This should not be surprising considering that EU case law must be adhered to by the CMA in accordance with sections 60(1)-(2) of the CA 98, which require it to ensure consistency of application of EU hard law. In addition, in light of the CMA's utilisation of the 'Applicable Law' section in its decisions, it seems that the primary way for the CMA to justify its references to soft law stems from their usefulness in dealing with EU hard law - in this case, EU case law.

82 Wolf Legal Publishers 2004), 16o; See also: Georgieva (n 24), $226 f$.

83

84
'Agreements or concerted practices that prevent, restrict or distort competition by object are
those that, by their very nature, have the potential to do so. This principle has been confirmed by the ECJ in a number of cases.'
86 Georgieva (n 16), 66f.

85 
A justification based solely on the section $60(3)$ consistency obligation without referring to case law in parallel can be seen in the second sub-category of references. In the Galvanised steel tanks decision, for example, the CMA applied the Horizontal Guidelines when establishing whether an information exchange had restrictive effects on competition. ${ }^{87}$ There, the Parties, in their Statements of Objection, argued on the basis of the Guidelines that their information exchange did not have any effects on fair competition. ${ }^{88}$ The CMA subsequently relied specifically on the Horizontal Guidelines to prove that, since the information exchange restricted competition by object in the first place, no consideration of factors related to effects on competition was necessary. ${ }^{89}$ In this case, the CMA openly engaged with the content of the Horizontal Guidelines, and such references were categorised as 'explicit - without case law.' Such a form of explicit acceptance is an even stronger recognition of the relevant soft law instrument, as the CMA feels a lesser need to justify its reliance through the use of EU case law.

The 'explicit - without case law' category of CMA references, however, does not appear to contradict the contention that the Authority strives to justify its reliance on soft law through EU case law. This is because in decisions such as Galvanised steel tanks, the soft law paragraphs to which the CMA refers are ultimately based on EU case law, ${ }^{\circ}$ rather than on novel content introduced by the Commission.

The last type of 'Explicit Acceptance' references worth mentioning is those regarding the Commission's Guidance Paper. It is widely acknowledged that the Guidance Paper has played a less active role in soft law's reception in Member States, since it is a document aimed at, together with summarising previous case law, outlining the Commission's enforcement priorities with regard to Article 102 abusive conduct..$^{11}$ As a result, numerous parts of the Guid-

87 Galvanised steel tanks Decision (n 69).

88 Ibid., ft 370: 'Balmoral refers to paragraphs 86 to 94 of the Commission's guidelines on the applicability of Article 101 TFEU to horizontal co-operation agreements, OJ (2011) C11/1. These paragraphs list various factors which are relevant in assessing the likely restrictive effect of an information exchange on competition. However, as noted at paragraph 4.36 above, in the case of a restriction of competition by object, it is not necessary to consider its effect on competition. Paragraph 74 of the Commission's horizontal co-operation guidelines state that 'information exchanges between competitors of individualised data regarding intended future prices or quantities should therefore be considered a restriction of competition by object. In addition, private exchanges between competitors of their individualised intentions regarding future prices or quantities would normally be considered and fined as cartels because they generally

89 Ibid. have the object of fixing prices or quantities.'

90 Horizontal Guidelines, paras 86-94.

91 Guidance Paper, para. 3. 
ance Paper significantly deviate from EU case law and practice. ${ }^{92}$ As Georgieva notes in her study on UK courts, it likely explains the poorer reception of the Guidance Paper in national practice. This can evidently be seen from the lower number of references made by the CMA to the document (11) compared to those made to other Guidelines.

For instance, in the Flybe Limited decision, one of the issues the CMA dealt with was whether Flybe's abusive conduct could be objectively justified. ${ }^{93} \mathrm{Ob}$ jective justifications are rooted in EU case law, recognising the reality that some conduct, although formally abusive, can be justified. ${ }^{94}$ However, in paragraph 30 of the Guidance Paper, the Commission further introduces that conduct can be objectively justified if the party can prove that its conduct produces efficiencies outweighing any anti-competitive effects. This is not based on any EU case law and is precisely the paragraph that the CMA refers to in the decision, according to which, 'in examining any claims that the conduct is justified by efficiencies, the European Commission's guidance sets out the cumulative conditions that a dominant undertaking will generally be expected to demonstrate, with a sufficient degree of probability, and on the basis of verifiable evidence, that it has met. ${ }^{95}$ Similarly, references have been made in the same decision to paragraph 26 of the document with regard to the use of average avoidable cost (hereinafter 'AAC') price setting. ${ }^{96}$ In other decisions, the CMA similarly based its analysis on paragraphs 28-31 of the Guidance Paper, which establish the efficiency doctrine as an objective justification. ${ }^{97}$

In spite of the above, references to the other Guidance Paper's paragraphs have been based on EU case law through either of the 'explicit acceptance' categories..$^{9}$ Hence, although the CMA's justification for relying on soft law instruments in its decisions is mostly based on case law, this is not so in all of its decisions. Inconsistencies, potentially caused by CMA's discretion with issues such as AAC and efficiencies justifications, therefore still remain.

92 Richard Whish, 'National competition law goals and the Commission's Guidance on Article 82 EC: the UK experience', in: Lorenzo Federico Pace (ed.), European Competition Law: The Impact of the Commission's Guidance on Article 102 (Edward Elgar 2011), 159ff.

93 OFT Decision Alleged abuse of a dominant position by Flybe Limited (2010) MPINF-PSWAoo1.

94 Case T-228/97, Irish Sugar plc v Commission of the European Communities [1999] EU:T:1999:246.

95 Flybe Limited Decision (n 93), para. 6.101.

$9^{6}$ Whish (n 92), 158; Flybe Limited Decision (n 93), $\mathrm{ft} 236$.

97 OFT Decision Abuse of a dominant position by Reckitt Benckiser Healthcare (UK) Limited and Reckitt Benckiser Group plc (2011) CE/8931/o8, para. 3.50.

98 E.g.: CMA Decision Unfair pricing in respect of the supply of phenytoin sodium capsules in the UK (2016) CE/9742-13, ft 774. 


\subsection{Acceptance - Implicit Recognition of Soft Law}

Two references were identified in which the CMA implicitly accepted the 101(3) Guidelines and thereby followed the 'persuaded judiciary' theory introduced earlier. Additionally, a decision in which the CMA came close to an implicit reference is discussed.

The first reference deals with the 101(3) Guidelines in the CMA's Tobacco decision. In paragraph 7.51, the Authority stated the following: 'the case law of the European Court makes clear that an agreement or concerted practice only meets the exemption conditions if it is demonstrated that it is more likely than not that the agreement or concerted practice must make it possible to obtain appreciable objective advantages of such a character as to compensate for the disadvantages for competition caused by the agreement or concerted practice. ${ }^{\prime 99}$ It then refers to the Consten and Grundig case, which laid the basis for objective advantages to consumers as a condition for the exemption criteria under Article 101(3) TFEU. ${ }^{100}$ However, it is unclear why, in this regard, the CMA did not engage with the 101(3) Guidelines which define the same concept as 'the net effect of the agreement must at least be neutral from the point of view of those consumers directly or likely affected by the agreement [, and that,] if such consumers are worse off following the agreement, the second condition of Article $81(3)$ is not fulfilled. ${ }^{101}$ In this paragraph, the Commission also refers to the Consten and Grundig case ${ }^{102}$ raising the question of why the CMA chose not to follow the Guidelines and instead directly relied on case law.

The second reference, also in the Tobacco decision to the same guidelines, was that 'the [CJEU] stated in its recent T-Mobile Netherlands judgment that agreements or concerted practices which have as their object the prevention, restriction or distortion of competition are those which can be regarded, "by their very nature", as being injurious to the proper functioning of normal competition. ${ }^{103}$ The same explanation that restrictions by object are harmful for competition is clearly stated in paragraph 21 of the 101(3) Guidelines.

Since the CMA similarly avoids the 101(3) Guidelines in both references and relies directly on case law, its outcome was the same as it would have been if it had applied the Guidelines. This is not surprising if one considers case law as the basis of the Guidelines. The references therefore seem to amount to an implicit acceptance of the Guideline's content by the CMA.

\footnotetext{
99 Tobacco Decision (n 67), para. 7.51.

100 Joined Cases 56 and 58/64, Etablissements Consten SARL and Grundig-Verkaufs-GmbHv Commission of the European Economic Community [1966] ECLI:EU:C:1966:41, paras 347-348.

101 101(3) Guidelines, para. 85.

102 Ibid., ft 80.

103 Tobacco Decision (n 67), para. 3.41.
} 
Another reference that could, at first sight, be categorised as an implicit acceptance was made in the Cardiff Bus decision. ${ }^{104}$ In paragraphs 7.156-7.158, the CMA stated that it will use the AAC as a standard for determining abusive sale prices. It must be noted that the CJEU had indeed mentioned in its $A K Z O$ ruling that sale prices higher than average variable costs (AVC) but below average total cost (ATC) would be considered abusive. ${ }^{105}$ However, in the Commission's Guidance Paper, it is suggested that the AAC standard, which most often leads to similar results, is also most likely to be used by the Commission. ${ }^{106}$ This suggestion that the AAC method is economically advantageous is - although not contradictory - inconsistent with prior CJEU case law. ${ }^{107}$ Moreover, it must be noted that at the point when the Cardiff Bus decision was issued in 2008, the Guidance Paper was not yet available; instead, DG Competition's Discussion Paper was published, ${ }^{108}$ the substance of which was almost identical to the Paper. ${ }^{109}$ Thus, since no EU case law was available in 2008 , the 'AAC' terminology could have come from the Discussion Paper and thereby influenced the CMA. It could have been so due to the document's status as a Discussion Paper and its formal value at the time.

However, by 2008, the CMA had already used the AAC standard in some of its previous decisions, such as Aberdeen Journals, ${ }^{110}$ as the Authority noted in paragraph 7.156 thereof. It is more likely, however, that the CMA merely used its discretion to follow the AAC methodology for appropriate price setting and, hence, did not actually rely on the Discussion Paper in the decision. Nevertheless, after the publication of the Guidance Paper in 2009, the CMA immediately began citing the Paper, suggesting that it felt more convenient to justify the AAC method by relying on the Paper, rather than by continuing to refer to its own practices. Since the CMA was not persuaded by the Paper, this cannot, therefore, be categorised as an implicit acceptance.

\subsection{Explicit and Implicit Refusal for Recognition of Soft Law}

The only instrument found to be rejected by the CMA was the Commission's Fine Imposition Guidelines. Its negative attitude to the Guidelines can also be inferred from the low number of references (2).

104 OFT Decision, Abuse of a dominant position by Cardiff Bus (2008) CE/5281/04, paras 7.156-7.158.

105 Case C-62/86, AKZO Chemie BVv EC Commission [1991] ECLI:EU:C:1991:286, para. 60.

106 Guidance Paper, para. 26; PInar Akman, 'The European Commission's guidance on article 102 TFEU: from inferno to paradiso?’ (2010) 73(4) Modern Law Review 605, G18ff.

107 Ibid.

108 Commission, 'DG Competition discussion paper on the application of Article 82 of the Treaty to exclusionary abuses' (2005); For the AAC standard, see paras 108-110 thereof.

109 Whish (n 92), 154ff.

110 OFT Decision Aberdeen Journals Ltd: alleged abuse of a dominant position (2003) CA98/14/2002. 
The decision in which an explicit refusal was identified was in Dairy Retail."1 As with other decisions, it starts out with several paragraphs on the consistency obligation and that the it must have regard to Commission-issued soft law. ${ }^{112}$ When the CMA considered the method of calculating penalties to be imposed on the Parties, it stated that: '(...) although the OFT's approach [to calculating the appropriate amount of fines] will be broadly consistent with the general principles applied by the Commission - such as the need to sanction the undertakings concerned and deter other undertakings as per the preamble to the Commission's guidelines - the OFT is not bound to adopt, in relation to the detail, the same methodology as the Commission, particularly where the Commission has itself a wide margin of discretion under its own guidelines. That would be tantamount to arguing that the OFT should apply the Commission's guidelines. Moreover, the OFT's duty under section $60(3)$ is at most only to have regard to any relevant decision or statement of the Commission.' ${ }^{113}$

In this paragraph the CMA states that it would not apply the same methodology as the Commission to the calculation of fines in the case. Since the Commission's methodology is equal, in essence, to the principles that guide it when setting fines, it can be said that the Fine Imposition Guidelines represent the Commission's methodology. ${ }^{114}$ The CMA further states that it will only be bound by the general principles that also guide the Commission, but not the more detailed Guidelines themselves. Furthermore, in the following sentence the CMA stresses that section 6o(3) only imposes a loose duty on it 'to have regard' to the Guidelines, thereby distancing itself from engaging with them. Although the CMA does rely on the Guidelines' preamble to express its agreement with general principles, it can be concluded that the Authority does not engage with the substance of the Guidelines at all. Hence, this is an instance of explicit refusal of the soft law instrument within the theoretical framework.

In addition, paragraph 7.8 states the following: 'The OFT does not consider that it is required by section 60 of the Act to calculate the penalties it imposes under the Act in the same manner as penalties imposed by the Commission (...) The OFT's primary obligation when calculating penalties under the [CA 98] is, therefore, to have regard to its [own] Penalty Guidance. Moreover, to the extent that that produces a different result from that which would arise from the approach adopted by the Commission, the OFT considers that such an outcome would be the consequence of a "relevant difference" between the provisions concerned under section 6o(1) of the Act. ${ }^{115}$ It can be argued that although at first sight the explicit rejection of the Guidelines would mean that

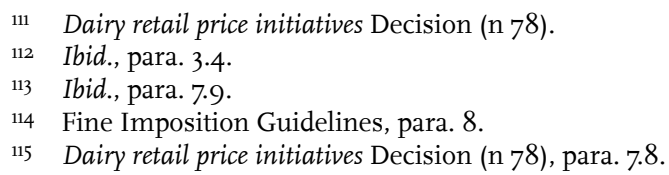


the instrument has no effects at all, from this paragraph it can be seen how the CMA follows the 'comply-or-explain' approach, pursuant to which each party can choose to either (a) conform to a soft law instrument or (b) deviate from it and explicitly state reasons for deviation from the instrument. ${ }^{116}$ In accordance with this principle, the CMA does not proceed with applying its own Penalty Guidelines whilst disregarding the Commission Guidelines, but rather chooses to first explain the legal basis for its refusal, basing it instead on section $60(1)$ of CA 98. ${ }^{117}$

The second decision in which a refusal of the Fine Imposition Guidelines was found was the Tobacco decision. Here, the issue the CMA had to deal with was identical to the one it dealt with in Dairy Retail; in fact, even the analysis and wording used by the Authority were identical. ${ }^{118}$ The only relevant difference was that, firstly, the two Parties were the first ones to rely on the Commission's Guidelines to determine the steps for calculating the fines; ${ }^{119}$ secondly, throughout the entire decision, the CMA only referred to the instrument as 'the Commission's guidance', and never properly referenced the Guidelines as it does with other soft law instruments. ${ }^{120}$ This must be interpreted as the CMA distancing itself even further from the Guidelines. Hence, according to the applied theoretical framework, this reference is categorised as an 'implicit refusal' of the Guidelines.

\section{Analysis of Trends}

Three important observations can be made from the above categorisation of the CMA's attitudes towards soft law instruments.

\subsection{The Likelihood of the CMA's Acceptance of Soft Law}

The overall attitude of the CMA is positive towards the Vertical Guidelines, 101(3) Guidelines, Horizontal Guidelines and the Guidance Paper, i.e. the CMA has referred to the instruments in most of its decisions. The justi-

116 Zlatina Georgieva, 'EU Competition Soft Law, National Courts and Multi-Level Enforcement: Certainty and Consistency Secured?' (on file with author), 21f; Emilia Korkea-Aho, 'EU soft law in domestic legal systems: flexibility and diversity guaranteed?’ (2009), 16(3) Maastricht Journal of European and Comparative Law 271 and 281.

117 Dairy retail price initiatives Decision ( $\mathrm{n} 78$ ), $\mathrm{ft}$ 1124: 'See comments in Hansard at the time the Competition Bill was being debated, such as the comment on behalf of the Government that section 60 was intended to import "high level principles, such as proportionality, legal certainty and administrative fairness" into domestic law'.

118 Tobacco Decision (n 67), paras 8.8-8.11.

119 Ibid., para. 8.8.

120 Ibid., para. 8.11. 
fications made by the Authority for using soft law is important to note in this regard. Firstly, in most decisions, a 'Consistency with European Union law' section is included. This allows the CMA to ground soft law early in each decision to avoid explaining its reliance on soft law each time it refers to it later in the judgment. This is consistent with the high number of subsequent references the CMA makes per decision. Secondly, in the majority of references, the CMA justified its reliance on soft law by either referring specifically to EU case law alongside soft law itself or by stipulating that a soft law instrument is, primarily, a summary of the relevant EU case law. In fact, in case of the former, the soft law content that the CMA refers to is in the first place based on case law. Therefore, it can already be said that the CMA is very likely to accept a soft law instrument if it is based on EU case law.

On the other hand, the CMA also made references in which it accepted the mentioned soft law where it was not based on any prior EU case law. This has been the case with references made to novel parts of the Guidance Paper, which, as Georgieva writes, were readily rejected by the courts in the UK. ${ }^{121}$ A number of explanations can be given for this. Firstly, such acceptance was only found in relation to 6 out of 11 references to the Guidance Paper. Moreover, references to the Guidance Paper formed only $13 \%$ of the references. The number of references to the Paper overall is low, meaning that, in other relevant decisions the CMA abstained from referring to the Paper in the first place. Secondly, out of those 6 references, the Authority could have merely used its discretion in interpreting Article 102 TFEU. It could have found solutions, such as the AAC fine calculation method or efficiency justifications to be the best interpretation of Article 102 and aimed to use it in any case, and therefore merely found it convenient to cite the approach in the Guidance Paper once it was published.

Hence, in general, the CMA is likelier to accept arguments based on soft law as long as it is based on EU case law. Similarly, it is less likely to do so when an instrument has no basis in case law. This is consistent with the practice witnessed in EU courts. ${ }^{122}$

\subsection{Referring to Case Law Versus Soft Law}

The second observation is that an explanation is yet to be found of the two 'implicit acceptance' references the CMA made to the 101(3) Guidelines in its Tobacco decision. At first sight, its first reference to the T-Mobile case ${ }^{123}$ could be justified by the fact that the 101(3) Guidelines had been published in

121 Georgieva (n 16), 74f; For example, see: Purple Parking Ltd, Meteor Parking Ltdv Heathrow Airport Ltd [2011] EWHC 987 (Ch).

122 Senden (n 82), 390.

123 Case C-8/o8, T-Mobile Netherlands BV and Others $v$ Raad van bestuur van de Nederlandse Mededingingsautoriteit [2009] ECR I- 04529, para. 29. 
2004, while the T-Mobile case was decided in 2009 and was therefore the most recent when the CMA made its decision in 2010. Nevertheless, this does not explain why the CMA did not engage with the 101(3) Guidelines in the other reference, choosing rather to cite the Consten and Grundig case from 1966.

Although more instances of such implicit references are likely to exist throughout the decisions, the discussion regarding the reasons behind this phenomenon are of small practical importance. This is because, as in the above references, the soft law content is ultimately endorsed by bypassing the instrument and relying on EU case law. Hence, it can be concluded that if a soft law provision can also be found in case law, then the CMA will accept it, be it explicitly or implicitly.

\subsection{Refusal of Recognition of the Fine Imposition Guidelines}

It has been seen that, in principle, no instances of refusal have been found with regard to the first four instruments.

The difference lies in the different nature of the instruments: the first four of them can be categorised as those providing guidance on the interpretation of substantive law, Articles 101 and 102 TFEU. The Fine Imposition Guidelines, on the contrary, aims at providing guidance on how penalties for fined undertakings should be calculated. This makes the Guidelines relevant for defining procedural law - a field that has not been harmonised under Regulation 1/2003 and EU law in general - which is applied on national level. Since the Commission and EU courts have less control over national procedural matters, the Fine Imposition Guidelines are less persuasive to the CMA. ${ }^{124}$ Moreover, both Article 23(2)(a) of Regulation 1/2003 as well as the preamble of the Guidelines state that the aim of the Guidelines is merely to improve transparency in the Commission's activities, therefore being of less relevance for national authorities. ${ }^{125}$ To conclude, it is the procedural nature of the Guidelines and the wider discretion of the CMA in setting fines that can lead to their rejection.

As it was mentioned above, ${ }^{126}$ the CMA nevertheless follows the "complyor-explain' principle, even if there is no legal obligation on the Authority to do so. Even though it is required under section 6o(3) of the CA 98 to 'have regard' to the Commission's soft law, this duty does not require it to follow the precise approach suggested by the Commission. This approach seems correct, since AG Kokott, in her Expedia opinion, also implies that a version of the 'comply-

124 See a similar trend in State Aid: Michelle Cini, 'The soft law approach: Commission rulemaking in the EU's state aid regime' (2001), 8(2) Journal of European Public Policy 192, $204 \mathrm{ff.}$

125 Oana Stefan, 'Hybridity Before the Court: A Hard Look at Soft Law in the EU Competition and State Aid Case Law' (2012) 37(1) EL Rev. 42, https://ssrn.com/abstract=2006729, accessed on 30 January 2018.

126 See Section 5.4. 
or-explain' principle should exist when stating that NCAs 'must give reasons which can be judicially reviewed for any divergences' either on a case-by-case basis or by publishing a general enforcement notice. ${ }^{127}$ This means that rejection in such form of the Guidelines can nevertheless be considered as having practical effects on parties.

\section{Conclusion}

The findings of this article allow for the conclusion that the CMA's use of EU soft law instruments is definitely not binary. On the one hand, the legal framework of the national duties with regard to EU soft law is far from clear, as it was seen in the CJEU's Grimaldi and Expedia lines of case law. Hence, little formal guidance has been provided to the CMA on the matter. On the other hand, the practice of the CMA has been seen to be rather consistent, albeit with exceptions. Several important conclusions have thus been established.

Although a precise delineation of soft law's legal and practical effects would be preferable for determining how the CMA uses soft law, such a delineation, as important as it may be, is purely theoretical. Thus, it was this article's purpose to assess how soft law is used by the CMA and, consequently, serve as a clarification for undertakings that wish to rely on soft law instruments in practice. The answer to the research question posed earlier is therefore three-fold. Firstly, the CMA is very likely to engage with EU substantive soft law instruments, provided they are in some way grounded in EU case law. Considering that most provisions of the substantive soft law instruments under consideration are based on EU case law, one can conclude that relying on such instruments is 'safe'. Moreover, it has been seen that even if the CMA does not want to engage with soft law, it will likely still do so implicitly through the case law on which it is based. Secondly, the CMA will also likely accept the provisions of the Guidance Paper that do not stem from case law, but which were introduced by the Commission. This result is different from what has been found with respect to the attitude of UK and Dutch courts, which seem more reluctant to accept soft law in these circumstances. ${ }^{128}$ Thirdly, it is concluded that the CMA is likely to refuse recognition of procedural soft law instruments such as the Fine Imposition Guidelines. However, even in such a case it can be expected to justify its refusal through a version of the 'comply-or-explain' principle.

127 Expedia case (n 52), Opinion of AG Kokott, para. 39 and $\mathrm{ft} 40$; Georgieva (n 116), 21-22.

128 See: Georgieva (n 16). 
Such an attitude of the CMA suggests that it considers the law to go beyond formal legislation, and therefore follows the hybridity theory in its decisions. ${ }^{129}$ Although it has been seen from EU case law and national practice that legally binding effects of soft law instruments do not exist, the practical effects of the five soft law instruments have nevertheless been determined in the CMA's practice. This can be seen not only from the fact that the CMA itself is likely to use EU soft law, but also from the instances in which parties have relied on soft law arguments with which the CMA readily engaged.

Of course, the UK's withdrawal from the EU as well as from the EEA will have a serious impact on the CMA's practice, as it will result in the non-application of EU law, including EU competition (soft) law, within the UK's territory. However, repealing the prohibitions under Chapters I and II of the CA 98 the provisions transposing Articles 101 and 102 TFEU - would seem radical because they have been shaping UK's competition law since it joined the EC. Simply substituting Chapters I and II with new competition laws would therefore cause unnecessary uncertainty. ${ }^{130}$ Instead, it seems likelier that the consistency obligation under section 60 of the CA 98 will be modified. ${ }^{131}$ Thus, the CMA's engagement with EU soft law post-Brexit remains to be seen as it will ultimately depend on the extent to which section 60 CA 98 will be modified.

Nevertheless, the findings of this article go beyond the role of EU soft law in CMA practice. They also aim to somewhat 'relax' the debate on soft law in the EU. With respect to NCAs and provided that the majority of EU soft law's substance amounts to a mere codification of pre-existing CJEU case law, its ample use does not seem to increase the democratic deficit in any significant way. This is so because such instruments do not introduce 'new law' by bypassing democratic safeguards. Yet, one cannot exclude the possibility that the Commission would codify an interpretation of CJEU case law favouring itself. This might in turn result in NCAs opportunistically choosing to rely on either the soft law instrument or case law that most favours their needs. Although this does not seem to have happened in the case of the CMA's decisions, this might well be a concern in other Member States.

It can also be concluded that, on the contrary, soft law succeeds in clarifying the often-complex bodies of 'hard' statutory and case law in fields as fast-paced as competition law. In light of the present need for flexible and dynamic governance, soft law might therefore be seen as a useful and 'harmless' tool. Further

129 David M. Trubek, M. Patrick Cottrell \& Mark Nance, “'Soft law”, "hard law”, and EU Integration', in: Gráinne de Búrca \& Joanne Scott (eds.), Law and New Governance in the EU and the US (Hart Publishing 2006), 65.

130 For a discussion on how the UK's competition law and policy could or should diverge from those of the EU post-Brexit, see: John Vickers, 'Consequences of Brexit for competition law and policy’ (2017) 33(1) Oxford Review of Economic Policy 70, $76 \mathrm{ff}$.

131 Ibid. 
EU SOFT LAW IN THE HANDS OF NATIONAL AUTHORITIES

research, however, should explore whether these findings can be generalised beyond the peculiarities of competition law. 